\title{
Contrasting effects of different levels of food intake and adiposity on LH secretion and hypothalamic gene expression in sheep
}

\author{
Z A Archer ${ }^{1,2}$, S M Rhind ${ }^{2}$, P A Findlay ${ }^{1}$, C E Kyle², L Thomas', \\ M Marie ${ }^{1}$ and C L Adam ${ }^{1}$ \\ ${ }^{1}$ Molecular Neuroendocrinology Group, Aberdeen Centre for Energy Balance and Obesity, Rowett Research Institute, Bucksburn, Aberdeen AB21 9SB, UK \\ ${ }^{2}$ Macaulay Land Use Research Institute, Craigiebuckler, Aberdeen AB15 8QH, UK \\ (Requests for offprints should be addressed to Z A Archer; Email: zaa@rri.sari.ac.uk)
}

\begin{abstract}
Body reserves (long-term) and food intake (short-term) both contribute nutritional feedback to the hypothalamus. Reproductive neuroendocrine output $(\mathrm{GnRH} / \mathrm{LH})$ is stimulated by increased food intake and not by high adiposity in sheep, but it is unknown whether appetiteregulating hypothalamic neurons show this differential response. Castrated male sheep (Scottish Blackface) with oestradiol implants were studied in two 4 week experiments. In Experiment 1, sheep were fed to maintain the initial body condition (BC) score of 2.0 $\pm 0 \cdot 00$ (lower BC (LBC), $n=7$ ) or $2 \cdot 9 \pm 0 \cdot 09$ (higher BC (HBC), $n=9$ ), and liveweight of $43 \pm 1 \cdot 1$ and $59 \pm 1 \cdot 6 \mathrm{~kg}$ respectively. LBC and HBC sheep had similar mean plasma LH concentration, pulse frequency and amplitude, but HBC animals had higher mean plasma concentrations of insulin $(P<0 \cdot 01)$, leptin $(P<0 \cdot 01)$ and glucose $(P<0 \cdot 01)$. Gene expression (measured by in situ hybridisation) in the hypothalamic arcuate nucleus (ARC) was higher in LBC than HBC sheep for neuropeptide Y (NPY; 486\% of HBC, $P<0.01$ ), agouti-related peptide (AGRP; 467\%, $P<0 \cdot 05)$ and leptin receptor (OB-Rb; $141 \%, P<0 \cdot 05)$, but lower for cocaine- and amphetamine-regulated transcript (CART; 92\%, $P<0.05)$ and similar between groups for pro-opiomelanocortin (POMC). In Experiment 2, sheep with initial mean BC score $2.4 \pm 0.03$ and liveweight $55 \pm 0 \cdot 8 \mathrm{~kg}$ were fed a liveweight-maintenance ration
\end{abstract}

(low intake, LI, $n=7$ ) while sheep with initial mean BC score $2 \cdot 0 \pm 0.03$ and liveweight $43 \pm 1 \cdot 4 \mathrm{~kg}$ were fed freely so that BC score increased to $2 \cdot 5 \pm 0.00$ and liveweight increased to $54 \pm 1.4 \mathrm{~kg}$ (high intake, HI, $n=9$ ). Compared with LI, HI sheep had higher mean plasma LH $(P<0 \cdot 05)$, baseline LH $(P<0 \cdot 01)$ and pulse amplitude $(P<0.01)$ and showed a trend towards higher pulse frequency. Although there were no differences in final mean plasma concentrations, there were significant increases over time in mean concentrations of insulin $(P<0 \cdot 001)$, leptin $(P<0 \cdot 05)$ and glucose $(P<0 \cdot 001)$ in HI sheep. Gene expression for AGRP in the ARC was higher in HI than LI animals (453\% of LI; $P<0 \cdot 05$ ), but expression levels were similar for NPY, OB-Rb, CART and POMC. Thus, the hypothalamus shows differential responses to steady-state adiposity as opposed to an increase in food intake, in terms of both reproductive neuroendocrine activity and hypothalamic appetiteregulating pathways. Differences in hypothalamic gene expression were largely consistent with contemporary levels of systemic leptin and insulin feedback; however, increased nutritional feedback was stimulatory to GnRH/LH whereas constant high feedback was not. The hypothalamus therefore has the ability to retain a nutritional memory that can influence subsequent responses.

Journal of Endocrinology (2002) 175, 383-393

\section{Introduction}

Nutritional feedback from the periphery to the hypothalamus regulates the appetite/bodyweight and reproductive neuroendocrine axes, and a comprehensive knowledge of how the hypothalamus responds to this feedback is critical for the understanding and control of appetite/bodyweight disorders, such as obesity, and infertility. Nutritional feedback comprises both long-term and short-term components derived from body energy reserves and contemporary food intake respectively, yet

these components are frequently confounded in animal experiments. However, reproductive neuroendocrine output, measured by pulsatile luteinising hormone (LH) secretion, is stimulated by short-term increases in food intake ('flushing') in ewes (Rhind et al. 1985, 1986, 1991) and rams (Martin \& Walkden-Brown 1995), but not by long-term increases in body fat reserves in ewes (Rhind \& McNeilly 1986, Rhind et al. 1989). Similarly, LH secretion is reduced in rams on restricted feeding, but pituitary LH content is not different between maintenance-fed rams with different levels of body fat 
(Alkass et al. 1982). Since LH secretion is an indirect measure of hypothalamic gonadotrophin-releasing hormone (GnRH) pulsatile output (Clarke \& Cummins 1982), these findings suggest that the hypothalamus can dissociate long- and short-term nutritional feedback with respect to GnRH activity. It is not known how the differential GnRH response is mediated or how the orexigenic-anorexigenic hypothalamic neuronal circuitry responds to the differential nutritional feedback.

Candidate signalling mechanisms for the provision of nutritional feedback from peripheral tissues to the hypothalamus include leptin and insulin, since their secretion is influenced by both body condition (BC) and food intake in sheep (Marie et al. 2001). Both hormones are implicated in nutritional modulation of reproduction (Blache et al. 2000a) and in appetite/bodyweight regulation (Schwartz et al. 2000). Insulin administered in physiological amounts into the ovine hypothalamus stimulates GnRH/LH (Miller et al. 1995). We have repeated this effect with physiological intracerebroventricular (i.c.v.) infusion of leptin (Miller et al. 2002), although published responses to pharmacological i.c.v. leptin administration of $\mathrm{GnRH} / \mathrm{LH}$ in sheep are variable (Henry et al. 1999, 2001a, Blache et al. 2000b, Morrison et al. 2001). Both hormones have also been shown to reduce appetite in sheep when given i.c.v. (Foster et al. 1991, Henry et al. 1999, 2001a, Blache et al. 2000b, Morrison et al. 2001).

Anatomical studies of gene expression have indicated that insulin receptors and leptin receptors $(\mathrm{OB}-\mathrm{Rb})$ are localised in the ovine hypothalamic arcuate nucleus (ARC) (Z A Archer, P A Findlay \& C L Adam, unpublished observations, and Williams et al. (1999) respectively). Studies in rodents suggest that leptin and insulin exert their actions on appetite and energy balance at least in part via the orexigenic neuropeptides neuropeptide Y (NPY) and agouti-related peptide (AGRP, melanocortin antagonist), and the anorexigenic proopiomelanocortin (POMC, melanocortin precursor) and cocaine- and amphetamine-regulated transcript (CART) neuronal pathways (reviewed by Schwartz et al. 2000). Gene expression for these neuropeptides has been localised in the ovine ARC (Adam et al. 2002). The roles of these orexigenic-anorexigenic pathways in the actions of insulin and leptin on GnRH secretion are unresolved, but $\mathrm{GnRH}$ cells have close synaptic contacts with both NPY and POMC neurons in rats (Kalra \& Kalra (1996) and Leranth et al. (1988) respectively). I.c.v. administration of NPY to sheep (Malven et al. 1992, McShane et al. 1992) and of the POMC product $\alpha$-melanocyte-stimulating hormone $(\alpha \mathrm{MSH})$ to rats (Gonzalez et al. 1997) inhibits GnRH/LH pulsatile secretion while AGRP administered i.c.v. stimulates GnRH/LH output in rats (Stanley et al. 1999) and CART stimulates GnRH release from rat hypothalamic explants in vitro (Lebrethon et al. 2000).
The castrated male with oestradiol replacement is an accepted model used in studies of nutrition-reproduction neuroendocrine interactions in sheep (e.g. Adam \& Findlay 1998, Nagatani et al. 2000) and was our model of choice for the present study. It avoids the changes in concentrations of circulating gonadal steroid seen across seasons in gonad-intact animals of both sexes and across the oestrous cycle in ewes, whilst providing a constant physiological level of gonadal steroid feedback to the hypothalamus. Furthermore, the GnRH/LH response to 'flushing' is observed in entire rams (Martin \& WalkdenBrown 1995), but not in castrated rams (Tjondronegoro et al. 1996), and is seen in ovariectomised ewes only in the presence of oestradiol (Rhind et al. 1989, 1991).

In order to extend our knowledge of hypothalamic responses to different scenarios of nutritional feedback, we investigated in sheep two experimental paradigms aimed at dissociating the effects of differential adiposity (at similar food intake) and differential food intake (at similar levels of adiposity). Measurements were made of systemic leptin and insulin concentration patterns and associated GnRH/LH secretion and hypothalamic ARC gene expression for OB-Rb, NPY, AGRP, POMC and CART. A differential GnRH/LH response was expected between these paradigms and we addressed the hypothesis that orexigenic and anorexigenic hypothalamic neuronal pathways would also exhibit differential responses.

\section{Materials and Methods}

\section{Animals and preparatory treatments}

Adult castrated male Scottish Blackface sheep $(n=32)$, with an initial mean liveweight $48 \pm 0.9 \mathrm{~kg}$ and $\mathrm{BC}$ score $2 \cdot 25 \pm 0 \cdot 02$ (scale $0=$ emaciated to $5=$ obese; Russel et al. (1969)), were housed in individual pens under natural photoperiod (August; $57^{\circ} \mathrm{N}$ ). Over a 9 week period prior to Experiments 1 and 2, each sheep was given $0.25 \mathrm{~kg}$ hay/day and an amount of pelleted concentrate feed calculated to induce the desired weight change (ranging from 0.2 to $2.5 \mathrm{~kg} /$ day) (Green Keil; North Eastern Farmers, Turriff, UK $(86 \cdot 1 \%$ dry matter (DM) and 12.5 MJ metabolisable energy (ME)/kg DM)). The amounts fed were adjusted as necessary on an individual basis with the objective of achieving four groups of sheep with mean BC scores of 2.0 and 3.0 at the beginning of Experiment 1, or $2 \cdot 0$ and 2.5 at the beginning of Experiment 2. No individual was required to increase or decrease more than $0.75 \mathrm{BC}$ score units. Food was given once daily at $0800 \mathrm{~h}$.

At 5 weeks before the beginning of the experiments two oestradiol-containing implants were inserted s.c. (Adam \& Findlay 1998). Circulating oestradiol concentration, determined by RIA with sensitivity $0.42 \mathrm{pg} / \mathrm{ml}$ (Mann et al. 1995), averaged $2 \cdot 1 \pm 0 \cdot 14 \mathrm{pg} / \mathrm{ml}$ (range $1 \cdot 03-3 \cdot 45 \mathrm{pg} / \mathrm{ml})$. 
All procedures were licensed under the UK Animals (Scientific Procedures) Act of 1986 and received prior approval from the Macaulay Land Use Research Institute's Ethical Review Committee.

\section{Experiment 1}

Mean initial BC scores were 2.0 $\pm 0 \cdot 00$ (lower BC (LBC), $n=7)$ and $2 \cdot 9 \pm 0.09$ (higher BC (HBC), $n=9)$, representing estimated body fat contents of 20 and $29 \%$ respectively (Russel et al. 1969); and mean initial liveweights were $43 \pm 1.1$ and $59 \pm 1.6 \mathrm{~kg}$ respectively. During the 4 week experimental period, the animals were fed individually a total amount calculated to maintain liveweight and $\mathrm{BC}$ score (0.42 MJ ME/ $\mathrm{kg}^{0 \cdot 75} /$ day; Robinson (1983)), comprising hay and pelleted feed given once daily as described above.

\section{Experiment 2}

Mean BC scores were 2.4 \pm 0.03 and $2 \cdot 0 \pm 0.03$ in the two groups at the beginning of the experimental period, representing body fat contents of 24 and $20 \%$ respectively (Russel et al. 1969); and mean initial liveweights were $55 \pm 0.8$ and $43 \pm 1.4 \mathrm{~kg}$ respectively. Animals of the BC $2 \cdot 4$ group were fed amounts calculated on an individual basis, as above, to maintain liveweight and BC score for 4 weeks (low intake (LI), $n=7$ ). Sheep in the BC $2 \cdot 0$ group were fed freely for 4 weeks so that their mean BC score would increase to approximately 2.5 (high intake $(\mathrm{HI}), n=9)$. The food refusals (15\% margin) were removed and recorded daily, just prior to the provision of fresh food at $0800 \mathrm{~h}$, in order to calculate voluntary food intake.

\section{Measurements and tissue collection}

Liveweights and BC scores were measured weekly, and voluntary food intakes were measured daily in the HI group. Blood samples were collected twice weekly, approximately $1.5 \mathrm{~h}$ after feeding, and immediately prior to killing. During week 4 of the experimental period, blood samples were collected via jugular catheters every $15 \mathrm{~min}$ for $7 \cdot 5 \mathrm{~h}$ ('pulse bleed'), starting at $0830 \mathrm{~h}$ (30 min after feeding), to determine pulsatile $\mathrm{LH}$ secretion. Plasma was stored at $-20{ }^{\circ} \mathrm{C}$ for subsequent $\mathrm{LH}$ analysis.

Within 1-2 days of the pulse bleed, sheep were killed by a lethal dose of sodium pentobarbitone (i.v.) (Euthesate; Willows Francis Veterinary, Crawley, Sussex, UK) between 0930 and $1630 \mathrm{~h}$, following feeding as usual at 0800 h. Cerebrospinal fluid (CSF) was sampled from the cisterna magna and stored at $-20{ }^{\circ} \mathrm{C}$; the brain was excised, snap-frozen in isopentane over dry ice and stored at $-80{ }^{\circ} \mathrm{C}$.

\section{Hormone and metabolite analyses}

Plasma concentrations of LH were measured by RIA (McNeilly et al. 1986) with an assay sensitivity of
$0 \cdot 2 \mathrm{ng} / \mathrm{ml}$ and intra- and inter-assay coefficient of variation $(\mathrm{CV})$ values of 4.4 and $12.9 \%$ respectively. Nonesterified fatty acid (NEFA) and glucose concentrations were determined by automated analysis, with sensitivity and intra- and inter-assay CV values of $0.04 \mathrm{mmol} / \mathrm{l}$, 2.0 and $4.0 \%$ respectively for NEFA (Matsubara et al. 1983 ), and $0.34 \mathrm{mmol} / 1,0.35$ and $2 \cdot 3 \%$ respectively for glucose (Peterson \& Young 1968). Leptin concentrations were determined by homologous RIA (Marie et al. 2001) in a single assay with a sensitivity of $0.45 \mathrm{ng} / \mathrm{ml}$ and intra-assay CV of $12.0 \%$. Insulin was measured by RIA (MacRae et al. 1991) in a single assay run showing sensitivity of $0.2 \mu \mathrm{IU} / \mathrm{ml}$ and an intra-assay $\mathrm{CV}$ of $2 \cdot 7 \%$.

\section{Hypothalamic gene expression}

Coronal cryostat sections $(20 \mu \mathrm{m})$ of hypothalamic tissue were thaw-mounted onto slides double-coated with gelatin and poly-L-lysine, and stored at $-80{ }^{\circ} \mathrm{C}$. Gene expression for OB-Rb, NPY, AGRP, POMC and CART was measured by in situ hybridisation, using techniques described in detail elsewhere (Mercer et al. 1995, Adam et al. 1997). A riboprobe complementary to fragments of the intracellular domain of OB-Rb was generated from a cloned sheep cDNA as described previously (Mercer $e t$ al. 1998). The NPY probe was generated from a rat cDNA and has been validated for use on sheep tissues (Adam et al. 1997). The CART probe was generated from a cloned sheep cDNA as described previously (Barrett et al. 2001). AGRP and POMC probes were generated from cloned Siberian hamster cDNAs (Mercer et al. 2000) and have been validated on sheep brain tissue (Adam et al. 2002). Briefly, sections were fixed, acetylated, and hybridised overnight at $58{ }^{\circ} \mathrm{C}$ using ${ }^{35} \mathrm{~S}$-labelled cRNA probes (1-1.5 $\times 107$ c.p.m./ml). They were then treated with RNase A, desalted, with a final high stringency wash (30 min) in $0.5 \times \mathrm{SSC}$ at $60^{\circ} \mathrm{C}$, dried and apposed to Hyperfilm $\beta$-max (Amersham Pharmacia Biotech UK Ltd, Little Chalfont, Bucks, UK). Intensity and total area of hybridisation over the ARC were quantified on each autoradiographic image, using the Image-Pro Plus system (Media Cybernetics, Silver Spring, MD, USA). The integrated intensity of the hybridisation signal was then computed using standard curves generated from ${ }^{14} \mathrm{C}$ autoradiographic micro-scales (Amersham Pharmacia Biotech). For each probe, three comparable sections from the medial hypothalamus (approximately $1.5-1.75 \mathrm{~mm}$ rostral from the opening of third ventricle) were analysed for each brain and the results averaged to give a single value for each animal. Within each experiment, all sections for a single probe were processed together and placed against the same sheet of autoradiographic film.

All reagents were obtained from Sigma (Sigma UK, Poole, Dorset, UK) unless otherwise stated. 
Table 1 CSF concentrations of glucose and insulin (means \pm S.E.M.) in sheep fed at liveweight maintenance with HBC or LBC (Experiment 1) and sheep with similar terminal $\mathrm{BC}$ scores fed freely $(\mathrm{HI})$ or a liveweight-maintenance ration (LI) (Experiment 2). Leptin concentrations were below the detection limit of the assay (i.e. less than $0.45 \mathrm{ng} / \mathrm{ml}$ ) in all groups. There were no significant differences

\begin{tabular}{|c|c|c|c|c|}
\hline & \multicolumn{2}{|l|}{ Experiment 1} & \multicolumn{2}{|c|}{ Experiment 2} \\
\hline & $\operatorname{HBC}(n=9)$ & LBC $(n=7)$ & $\mathrm{LI}(n=7)$ & $\mathrm{HI}(n=9)$ \\
\hline Glucose (mmol/l) & $2 \cdot 3 \pm 0 \cdot 14$ & $2 \cdot 0 \pm 0 \cdot 19$ & $2 \cdot 2 \pm 0 \cdot 12$ & $2 \cdot 2 \pm 0 \cdot 11$ \\
\hline Insulin $(\mu \mathrm{IU} / \mathrm{ml})$ & $3 \cdot 7 \pm 0 \cdot 18$ & $3 \cdot 7 \pm 0 \cdot 53$ & $3 \cdot 6 \pm 0 \cdot 20$ & $3 \cdot 9 \pm 0 \cdot 21$ \\
\hline
\end{tabular}

\section{Statistical analyses}

Mean \pm S.E.M. values are reported and the probability value used for statistical significance was $P<0 \cdot 05$. Initially, mean plasma concentrations of insulin, leptin, glucose and NEFA for the duration of the experiments were calculated within individuals and compared between treatment groups within Experiments 1 and 2 using two-sample $t$-tests. The trends in these parameters over time appeared relatively linear and were therefore analysed by comparing mean linear trend coefficients (regression slopes) (Diggle et al. 1994). Linear regression slopes were calculated for each animal for each parameter over the 4 week experimental period and confidence intervals for the regression slopes were used to assess whether values changed over time. Comparison of the linear regression slopes using two-sample $t$-tests was undertaken to assess the difference in the trends between groups (treatment $\times$ time interaction) within each experiment. Linear regressions of $\mathrm{BC}$ score and food intake against time were similarly compared between groups using two-sample $t$-tests.

LH profiles were analysed using PulseFit (Version 1.3; R H Kushler, Department of Mathematical Sciences, Rochester, MI, USA), which provided values for LH pulse frequency, pulse amplitude and baseline concentrations. In addition, within-animal mean concentrations were calculated for each pulse bleed profile ('mean LH'). Treatment effects on pulse amplitude, baseline LH and mean LH were analysed by one-way ANOVA and effects on LH pulse frequency by Wilcoxon Mann-Whitney tests. Levels of gene expression were compared between the groups within each experiment by one-way ANOVA. All statistical tests were carried out using Microsoft Excel 97 (Microsoft, Redmond, WA, USA).

\section{Results}

Liveweight, BC and food intake

Experiment $1 \mathrm{LBC}$ and $\mathrm{HBC}$ groups maintained $\mathrm{BC}$ scores throughout the experimental period and had final mean BC scores $2 \cdot 0 \pm 0 \cdot 00$ and $2 \cdot 9 \pm 0 \cdot 09$ respectively. Mean liveweight was consistently lower in LBC than
HBC animals, with final mean liveweights of $43 \cdot 1 \pm 0.94$ and $62.4 \pm 1.49 \mathrm{~kg}$ respectively $(P<0 \cdot 001 ;$ Fig. 1$)$. The mean daily food intake required to maintain liveweight was lower for the LBC than HBC group $(12 \cdot 4 \pm 1 \cdot 27$ vs $18.8 \pm 1 \cdot 25 \mathrm{~g} \mathrm{DM} / \mathrm{kg}$ liveweight respectively, $P<0 \cdot 01$; Fig. 1).

Experiment 2 LI sheep maintained the same BC score throughout (mean final BC score $2 \cdot 4 \pm 0 \cdot 03$ ). The mean BC score of the HI animals increased from $2 \cdot 0 \pm 0 \cdot 01$ to $2 \cdot 5 \pm 0 \cdot 00$. The mean liveweight of the LI group was maintained throughout the study period (final liveweight $56 \cdot 7 \pm 1 \cdot 16 \mathrm{~kg}$ ), whereas that of the HI group increased during the 4 week period from $42.8 \pm 1 \cdot 37$ to $53.7 \pm 1.39 \mathrm{~kg}$ at killing. The mean daily food intake of the HI group was consistently higher than that of the LI group, with mean daily intakes over the final week of $37.3 \pm 3.32$ and $18.9 \pm 1.38 \mathrm{~g} \mathrm{DM} / \mathrm{kg}$ liveweight respectively $(P<0 \cdot 001)$ (Fig. 1$)$.

\section{Plasma and CSF profiles}

Experiment 1 Compared with LBC sheep, HBC sheep had higher mean plasma glucose $(P<0 \cdot 01)$, insulin $(P<0 \cdot 01)$ and leptin $(P<0 \cdot 01)$, and similar concentrations of NEFA (Fig. 1). In both groups there was no change over time for glucose and NEFA concentrations, and no significant treatment $\times$ time interaction for glucose, insulin and NEFA (Fig. 1). Plasma concentrations of insulin increased over time in both $\operatorname{HBC}(P<0.01)$ and LBC $(P<0 \cdot 05)$ groups (Fig. 1). Plasma leptin concentrations decreased over time in both $\operatorname{HBC}(P<0 \cdot 05)$ and LBC $(P<0.05)$ animals and there was a significant treatment $\times$ time interaction $(P<0 \cdot 01)$ (Fig. 1). Mean CSF concentrations of glucose and insulin were not significantly different between HBC and LBC sheep, and leptin concentrations were below the detection limit of the assay (Table 1).

Experiment 2 There were no significant differences between treatment groups in overall mean plasma concentrations of glucose, NEFA, insulin and leptin (Fig. 1). 

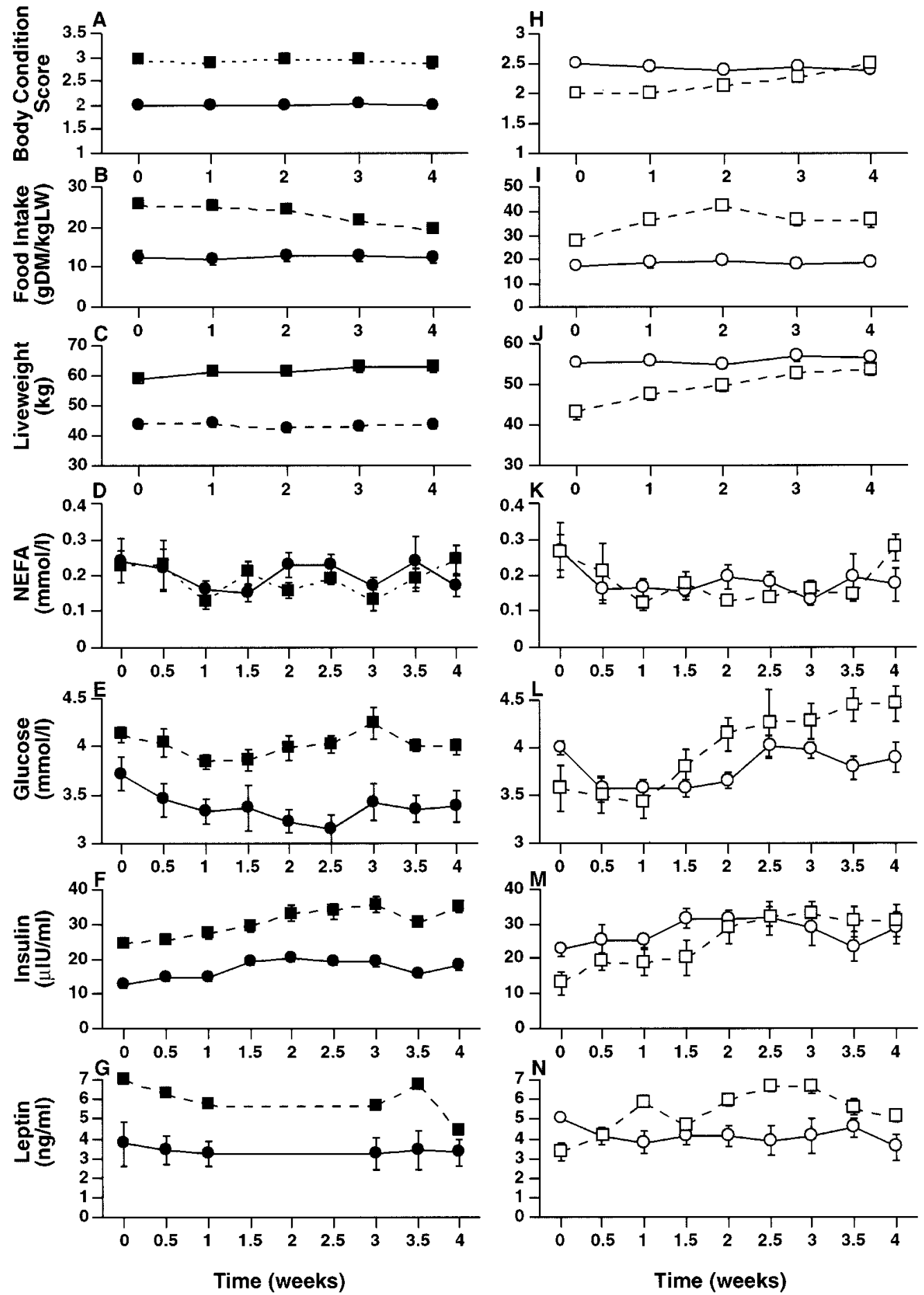

Figure 1 Mean BC score, daily food intake, liveweight, and plasma concentrations of NEFAs, glucose, insulin and leptin (means \pm S.E.M.) in sheep in $\operatorname{HBC}(\boldsymbol{\square} ; n=9)$ or $\operatorname{LBC}(\boldsymbol{\theta} ; n=7)$ and fed a liveweight-maintenance ration (Experiment $1 ; \mathrm{A}-\mathrm{G}$ ) and sheep with similar terminal $\mathrm{BC}$ scores fed freely $(\mathrm{HI}(\square) ; n=9$ ) or a liveweight-maintenance ration $(\mathrm{LI}(\mathrm{O}) ; n=7)$ (Experiment $2 ; \mathrm{H}-\mathrm{N})$. 
Table $2 \mathrm{LH}$ secretory parameters (means \pm S.E.M.) for sheep fed at liveweight maintenance with HBC or LBC (Experiment 1) and sheep with similar terminal BC scores fed freely (HI) or a liveweight-maintenance ration (LI) (Experiment 2)

\begin{tabular}{|c|c|c|c|c|}
\hline & \multicolumn{2}{|c|}{ Experiment 1} & \multicolumn{2}{|c|}{ Experiment 2} \\
\hline & $\operatorname{HBC}(n=9)$ & $\operatorname{LBC}(n=7)$ & $\mathrm{LI}(n=7)$ & $\mathrm{HI}(n=9)$ \\
\hline Mean LH (ng/ml) & $2 \cdot 8 \pm 0 \cdot 36$ & $3 \cdot 1 \pm 0 \cdot 75$ & $2 \cdot 3 \pm 0 \cdot 22$ & $3 \cdot 7 \pm 0 \cdot 49 *$ \\
\hline Pulse frequency (pulses $/ 7 \cdot 5 \mathrm{~h}$ ) & $2 \cdot 3 \pm 0 \cdot 28$ & $2 \cdot 7 \pm 0 \cdot 42$ & $1 \cdot 9 \pm 0 \cdot 34$ & $2 \cdot 9 \pm 0.51\left(^{*}\right)$ \\
\hline Pulse amplitude (ng/ml) & $1 \cdot 3 \pm 0 \cdot 22$ & $1 \cdot 5 \pm 0 \cdot 47$ & $0 \cdot 9 \pm 0 \cdot 30$ & $2 \cdot 1 \pm 0 \cdot 31^{* *}$ \\
\hline Baseline LH (ng/ml) & $2 \cdot 1 \pm 0 \cdot 31$ & $2 \cdot 1 \pm 0 \cdot 61$ & $1 \cdot 8 \pm 0 \cdot 22$ & $3 \cdot 1 \pm 0 \cdot 40^{* *}$ \\
\hline
\end{tabular}

However, in the HI group, there were significant increases over time in mean circulating glucose $(P<0 \cdot 001)$, insulin $(P<0 \cdot 001)$ and leptin $(P<0 \cdot 05)$ (Fig. 1). There was no change over time in LI sheep and so there were significant interactions between treatment and time for plasma glucose $(P<0 \cdot 001)$, insulin $(P=0 \cdot 001)$ and leptin $(P<0 \cdot 01)$. NEFA concentrations showed no significant change over time and no treatment $\times$ time interaction (Fig. 1). Mean CSF concentrations of glucose and insulin were not significantly different between HI and LI sheep, and leptin concentrations were below the detection limit of the assay (Table 1).

\section{LH secretion}

Experiment 1 Mean LH, LH pulse frequency, pulse amplitude and basal LH concentrations did not differ significantly between LBC and HBC groups (Table 2).

Experiment $2 \mathrm{HI}$ animals exhibited higher mean LH $(P<0 \cdot 05)$, higher mean LH pulse amplitude $(P<0 \cdot 01)$ and higher mean basal LH concentrations $(P<0 \cdot 01)$ than LI animals (Table 2). There was a trend towards higher $\mathrm{LH}$ pulse frequency in HI than LI animals $(P<0 \cdot 10)$ (Table 2).

\section{Hypothalamic gene expression}

All mRNA species examined were localised to the ARC, with $\mathrm{OB}-\mathrm{Rb}$ also being found in the ventromedial hypothalamus. Sense probes showed no hybridisation. Quantification was carried out only in the ARC.

Experiment 1 Compared with the HBC group, LBC sheep had higher levels of gene expression in the ARC for OB-Rb $(P<0 \cdot 05)$, NPY $(P<0 \cdot 01)$ and AGRP $(P<0 \cdot 05)$, lower amounts of CART $(P<0 \cdot 05)$, and similar amounts of POMC mRNA (Figs 2 and 3).

Experiment 2 There were no differences in ARC gene expression between the groups for OB-Rb, NPY, CART and POMC, but AGRP gene expression was higher in $\mathrm{HI}$ than LI animals $(P<0 \cdot 05)$ (Fig. 3).

\section{Discussion}

The two prescribed paradigms of contrasting nutritional status were achieved in Experiments 1 and 2. The increased LH output (and by inference GnRH output) observed with high vs low food intake (Experiment 2) and not in HBC vs LBC score (Experiment 1) agreed with previous findings (Rhind et al. 1985, 1986, 1989, 1991, Rhind \& McNeilly 1986). The present data support our hypothesis that in addition to these differential effects on GnRH secretion, there were differential effects on hypothalamic gene expression in the ARC for orexigenic and anorexigenic neuropeptide systems. Overall, the results suggest that the hypothalamus is able to differentiate between constant and increasing nutritional feedback (perhaps mediated by leptin and insulin) as evidenced by the differential responses shown by both hypothalamic appetite-regulating and reproductive neuroendocrine pathways.

The contrast in nutritional state in Experiment 1 lay in the differential steady-state adiposity between the groups. Food intake was functionally similar since it was restricted on an individual basis to the amount required to maintain liveweight for the 4 weeks of experiment and, as indicated by circulating NEFA values, fat mobilisation was insignificant in both groups. Plasma concentrations of glucose, insulin and leptin were all consistently higher in the higher adiposity (HBC) than in the lower adiposity (LBC) sheep, in agreement with previous findings (McCann et al. 1992, Blache et al. 2000c, Delavaud et al. 2000, Marie et al. 2001).

The contrast in nutritional state achieved in Experiment 2 was not solely represented by the terminal state of different level of food intake at the same level of adiposity. The nutritional state in the 4 weeks preceding killing had been dynamically increasing in the freely-fed (HI) sheep but had been relatively constant in the maintenance-fed (LI) sheep. Again fat mobilisation was negligible in both groups, as evidenced by their similar plasma NEFA concentrations, but plasma concentrations of glucose, insulin and leptin increased in the HI sheep during the 4 week study to reach concentrations similar to the steady- 


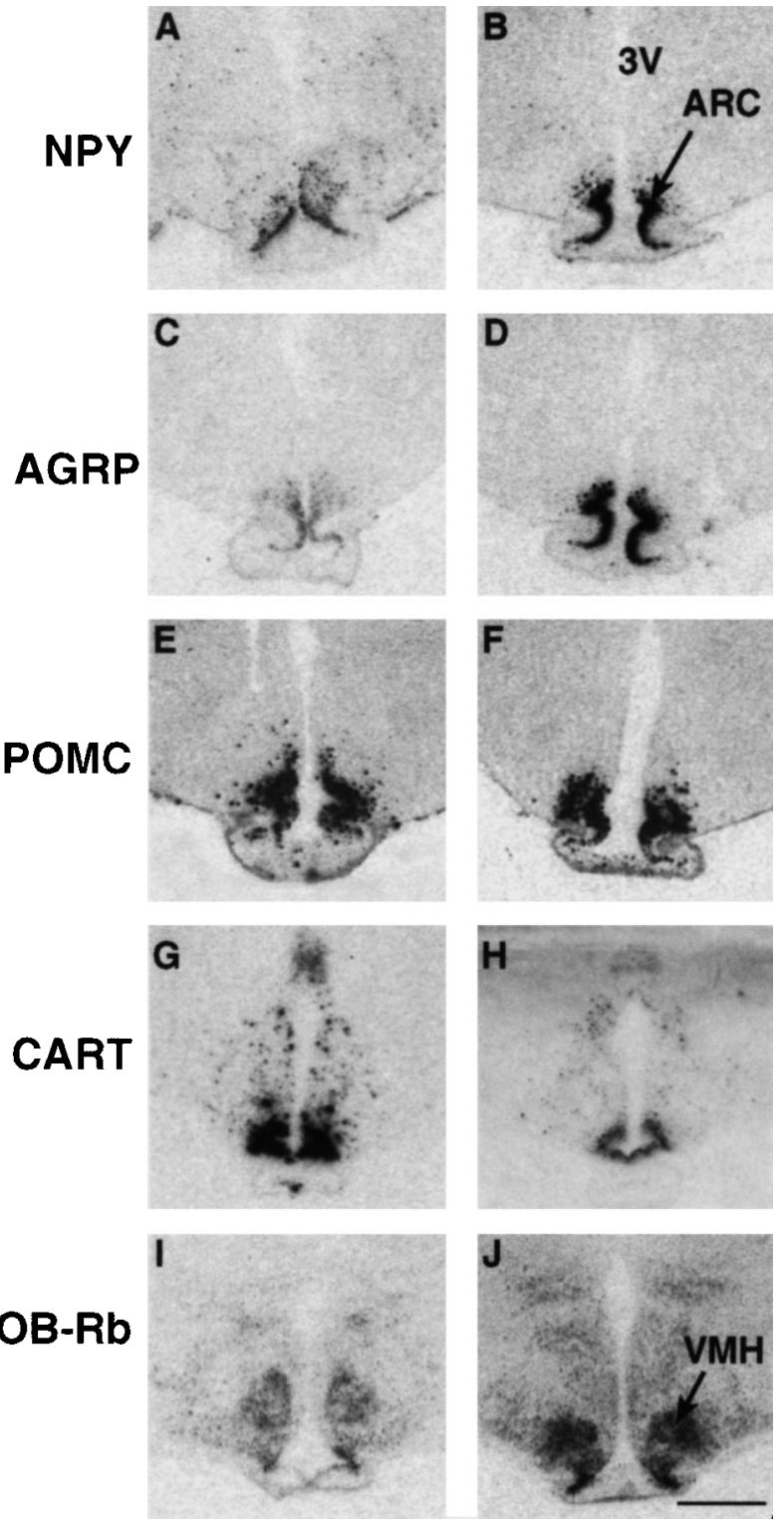

Figure 2 Representative autoradiographic images of hypothalamic ARC gene expression for NPY, AGRP, POMC, CART and OB-Rb in sheep fed a liveweight-maintenance ration with $\mathrm{HBC}(\mathrm{A}, \mathrm{C}, \mathrm{E}$, $\mathrm{G}, \mathrm{I})$ or $\mathrm{LBC}(\mathrm{B}, \mathrm{D}, \mathrm{F}, \mathrm{H}$, J; Experiment 1). 3V, third ventricle; $\mathrm{VMH}$, ventromedial hypothalamus. Bar $=3 \mathrm{~mm}$.

state values recorded in the LI sheep throughout the study. Thus, at the time of killing, the key difference in the signal provided by circulating levels of insulin and/or leptin to the hypothalamus lay not in the concentration of hormone on that day but in the preceding pattern of feedback.

The extent to which systemic feedback to the ARC is exerted through changes in CSF concentrations is uncertain. Although glucose, insulin and leptin have all

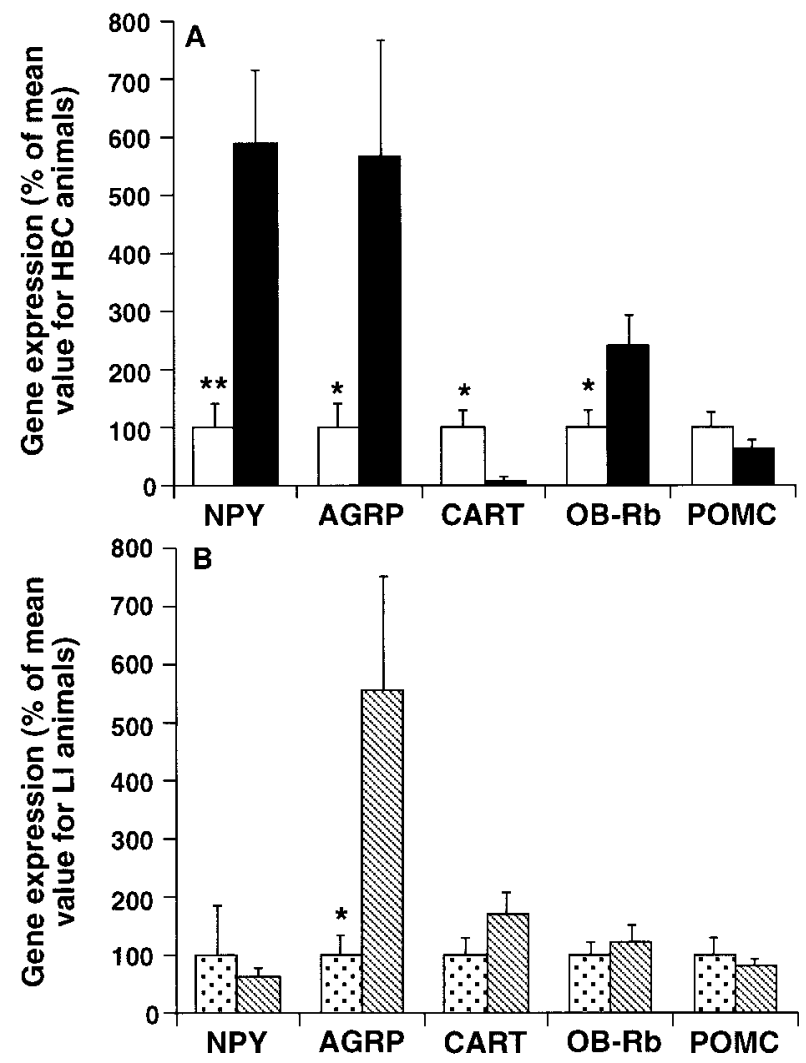

Figure 3 Hypothalamic ARC gene expression (means \pm S.E.M.) for NPY, AGRP, POMC, CART and OB-Rb in (A) sheep with HBC (open bars) or LBC (solid bars) and fed a liveweight-maintenance ration (Experiment 1 ) and (B) sheep with similar terminal $B C$ scores fed freely ( $\mathrm{HI}$; striped bars) or a liveweight-maintenance ration (LI; dotted bars) (Experiment 2). ${ }^{*} P<0 \cdot 05,{ }^{* *} P<0 \cdot 01$.

been detected in ovine CSF (Miller et al. 1998, Blache et al. 2000c), there were no treatment differences in glucose and insulin concentrations in the CSF in this study, irrespective of differences in concentrations in plasma, and leptin values were below detection. However, it is acknowledged that in Experiment 2 critical progressive changes as seen in the plasma concentrations of these factors (Fig. 1) may have occurred in the CSF but remained undetected.

Studies of gene expression of hypothalamic orexigenic and anorexigenic neuropeptides have most commonly been undertaken in rodents following acute challenge paradigms such as fasting or food restriction. In sheep the relatively few such studies have been carried out using chronic food restriction paradigms (McShane et al. 1993, Adam et al. 1997, Henry et al. 2000) or fasting (Adam et al. 2002). The effects on hypothalamic gene expression of food intake and adiposity have not previously been dissociated. Long-term alterations in adiposity were studied previously by Henry et al. (2000) but their model differs fundamentally from the present one in that their 
'fat' sheep continued to feed freely (and were therefore satiated) while the 'thin' counterparts had their intake restricted to liveweight maintenance. Sheep in our differential adiposity model (Experiment 1) are all restricted to the same (liveweight maintenance) level of intake for the 4 weeks prior to killing. Furthermore, our model presents a more modest adiposity differential (20 vs $29 \%$ body fat) than that of Henry et al. (2000) (15 vs 36\% body fat). Nonetheless, results from the two models are in general agreement, with increased NPY and AGRP and no difference in POMC gene expression between thin and fat sheep (Henry et al. 2000, 2001b); here, we additionally report elevated $\mathrm{OB}-\mathrm{Rb}$ and reduced CART gene expression in the ARC of thin vs fat sheep. Hypothalamic gene expression in sheep has not previously been reported for the contrasting paradigm of differential food intake at the same level of adiposity (Experiment 2). In this scenario, the only difference observed was a higher level of AGRP gene expression in the ARC of $\mathrm{HI}$ vs LI sheep.

Differences in ARC gene expression between HBC and LBC animals (Experiment 1) were largely consistent with putative induction by the differences in circulating insulin and leptin. NPY mRNA expression was lower in HBC than LBC animals and this was associated with higher plasma concentrations of insulin and leptin, both of which have been shown to suppress NPY mRNA when administered i.c.v. (Schwartz et al. 1992, Henry et al. 1999). NPY mRNA co-localises with OB-Rb in the ovine ARC (Williams et al. 1999), and the simultaneous up-regulation of both mRNAs in LBC sheep is suggestive of a leptin-driven response (Ahima et al. 2000). The absence of differences in gene expression for both OB-Rb and NPY between HI and LI sheep (Experiment 2) was consistent with their similar terminal BC scores and plasma leptin and insulin concentrations. However, since their initial BC scores were clearly different, extrapolating from the results of Experiment 1, it is postulated that NPY and $\mathrm{OB}-\mathrm{Rb}$ gene expression were initially higher in $\mathrm{HI}$ than LI animals. Levels of expression then steadily declined in HI sheep inversely associated with the circulatory increases in insulin and leptin, so that they were similar to those in LI sheep by the end of the study period.

AGRP gene expression, like NPY gene expression, was higher in LBC than HBC animals (Experiment 1), which was consistent with suppression by the increased circulating leptin (Wilson et al. 1999). However, unlike NPY gene expression, AGRP gene expression in the ARC was higher in $\mathrm{HI}$ than LI animals (Experiment 2) despite their similar final plasma concentrations of insulin and leptin. Possible reasons are: (i) gene expression for AGRP was unresponsive to the increasing circulating concentrations of insulin and leptin, (ii) AGRP had a greater response time than NPY to the circulatory changes in insulin and leptin, (iii) there was a greater initial level of expression in animals of the HI group, attributable to their low initial
$\mathrm{BC}$, and expression was still decreasing after 4 weeks, or (iv) AGRP gene expression is regulated by other factor(s). Since AGRP and NPY mRNAs are co-expressed within the ARC of rodents (Mercer et al. 2000), findings from the present study suggest either that there was transcriptspecific regulation within NPY/AGRP-expressing neurons or that different neuronal sub-populations were activated.

AGRP antagonises the actions of the POMC products $\alpha \mathrm{MSH}$ and $\gamma \mathrm{MSH}$ at their brain receptors, thus mediating orexigenic actions by suppressing the melanocortin feedback pathway (Cone 1999). However, POMC gene expression was not affected by $\mathrm{BC}$ or food intake in this study. This is consistent with the previous report that long-term alterations in adiposity and intake did not affect hypothalamic POMC expression in ovariectomised ewes (Henry et al. 2000). Conversely CART mRNA, which extensively co-localises in the ARC with POMC mRNA (rodent: Elias et al. 1998, sheep: Adam et al. 2002), was up-regulated in HBC vs LBC sheep in Experiment 1, unlike the results of Henry et al. (2001b); this is also suggestive of transcript-specific regulation within single neurons. Leptin concentrations were different between the groups in Experiment 1, but not at the time of killing in Experiment 2. The apparent sensitivity of CART gene expression to the steady-state level of adiposity (Experiment 1) but not to differing levels of food intake (Experiment 2) was therefore perhaps indicative of its acute sensitivity to the amount of leptin feedback (Kristensen et al. 1998) and of its rapid response to changes in circulating leptin.

There is increasing support for the concept of bodyweight regulation incorporating an 'appropriate bodyweight' target which is encoded within the brain, against which nutritional feedback is compared, and responses are integrated within the hypothalamus (Mercer \& Speakman 2001). Thus, it is postulated that feedback in underweight individuals activates orexigenic hypothalamic pathways to attempt to restore appropriate bodyweight, and in overweight individuals activates anorexigenic systems. On the basis of the observed patterns of neuropeptide expression, it is suggested that the hypothalamus of LBC sheep in Experiment 1 perceived that bodyweight was substantially sub-optimal; appropriate orexigenic pathways (NPY, AGRP) were therefore activated and anorexigenic pathways (CART) were suppressed to attempt to restore optimum bodyweight. Conversely the HI sheep in Experiment 2 had achieved similar bodyweight to their LI counterparts at killing, so that activities of the orexigenic NPY and anorexigenic CART pathways had equalised between the groups. Only AGRP remained differentially expressed, for reasons that are open to conjecture.

The extent to which observed differences in hypothalamic gene expression were likely to have been involved in mediating effects on GnRH secretion in the present study is open to speculation. Indeed, anomalies are 
revealed in putative neuropeptide-GnRH relationships. Thus, increased ARC gene expression for NPY was not associated with decreased reproductive neuroendocrine activity in Experiment 1, in contrast to McShane et al. (1993) and Adam et al. (1997), and increased AGRP gene expression was not associated with increased GnRH/LH output, in contrast to the findings of Stanley et al. (1999). However, GnRH/LH output was stimulated in the group exhibiting elevated AGRP gene expression in Experiment 2, which would be consistent with the findings of Stanley et al. (1999). It is therefore possible that either the relative activity of these neuropeptide systems is the critical factor determining $\mathrm{GnRH}$ secretion patterns or that alternative unknown mediators are involved. Nonetheless, synaptic contacts are known to exist that indicate interactive capability between GnRH cells and NPY and POMC/CART neurons (Tillet et al. (1989) and Elias et al. (1998) respectively). The anomalies may potentially be explained by changes in gene expression over time, driven perhaps by the circulatory changes in insulin and leptin, which might be critical in dictating the $\mathrm{GnRH}$ response.

In conclusion, the present models have demonstrated contrasting hypothalamic responses to steady-state adiposity as opposed to an increase in food intake, in terms of both reproductive neuroendocrine activity and gene expression for hypothalamic appetite-regulating neuronal systems. However, it is clearly difficult to dissociate completely the systemic signal(s) from intake and from adipose tissue since changes in intake over time lead to changes in adiposity. Here, circulating concentrations of leptin and insulin appeared to reflect both food intake and adiposity, providing a composite signal of nutritional status in both models. Interpretation is further confounded by the ability to determine ongoing metabolic endocrine status over time but to examine hypothalamic gene expression only at a single time point. Nonetheless, the observed differences in hypothalamic gene expression for the appetite-regulating neuropeptides, with the exception of AGRP, were consistent with the contemporary level of nutritional feedback provided by these hormones. However, the difference in GnRH/LH response between the models was not consistent with mediation by the level of contemporary nutritional feedback per se but by its state of change; thus, increased nutritional feedback was stimulatory but constant high feedback was not. This suggests that the GnRH response to nutrition results from computation within the hypothalamus of dynamic changes in nutritional feedback, which may involve the appetiteregulatory pathways studied or alternative intermediary neuronal mechanisms. Overall, the GnRH response demonstrates the ability of the hypothalamus to retain a nutritional memory that can influence subsequent responses to nutritional feedback, with potential relevance for the treatment of appetite/bodyweight disorders such as obesity as well as infertility.

\section{Acknowledgements}

This research was funded by Scottish Executive Environment and Rural Affairs Department. Z A A was in receipt of a Boyd Orr Research Centre studentship. We thank Drs N Hoggard, J Mercer, A Ross, P Barrett and S Sabol for probes, M Annand for NEFA and glucose analyses, F Gebbie for oestradiol analyses, T Atkinson for iodinations, N Hoggard for assistance with the leptin antibody, Macaulay Land Use Research Institute Glensaugh Research Station animal house staff for daily animal care, the National Institute of Diabetes and Digestive and Kidney Diseases and the Scottish Antibody Production Unit for RIA materials and G Horgan of Biomathematics \& Statistics Scotland for statistical advice.

\section{References}

Adam CL \& Findlay PA 1998 Inhibition of luteinizing hormone secretion and expression of $\mathrm{c}$-fos and corticotrophin-releasing factor genes in the paraventricular nucleus during insulin-induced hypoglycaemia in sheep. Journal of Neuroendocrinology 10 777-783.

Adam CL, Findlay PA, Kyle CE, Young P \& Mercer JG 1997 Effect of chronic food restriction on pulsatile luteinizing hormone secretion and hypothalamic neuropeptide Y gene expression in castrate male sheep. Journal of Endocrinology 152 329-337.

Adam CL, Archer ZA, Findlay PA, Thomas L \& Marie M 2002 Hypothalamic gene expression in sheep for cocaine- and amphetamine-regulated transcript, pro-opiomelanocortin, neuropeptide $Y$, agouti-related peptide and leptin receptor, and responses to negative energy balance. Neuroendocrinology 75 250-256.

Ahima RS, Saper, CB, Klier JS \& Elmquist JK 2000 Leptin regulation of neuroendocrine systems. Frontiers of Neuroendocrinology 21 263-307.

Alkass JE, Bryant MJ \& Walton JS 1982 Some effects of level of feeding and body condition upon sperm production and gonadotropin concentrations in the ram. Animal Production 34 265-277.

Barrett P, Morris MA, Moar KM, Mercer JG, Davidison JA, Findlay PA, Adam CL \& Morgan PJ 2001 The differential regulation of CART gene expression in a pituitary cell line and primary cell cultures of ovine pars tuberalis cells. Journal of Neuroendocrinology 13 $347-352$

Blache D, Chagas LM, Blackberry MA, Vercoe PE \& Martin GB $2000 a$ Metabolic factors affecting the reproductive axis in male sheep. Journal of Reproduction and Fertility 120 1-11.

Blache D, Celi P, Blackberrv MA, Dynes RA \& Martin GB $2000 b$ Decrease in voluntary feed intake and pulsatile luteinizing hormone secretion after intracerebroventricular infusion of recombinant bovine leptin in mature male sheep. Reproduction, Fertility, and Development 12 373-381.

Blache D, Tellam RL, Chagas LM, Blackberry MA, Vercoe PE \& Martin GB 2000c Level of nutrition affects leptin concentrations in plasma and cerebrospinal fluid in sheep. Journal of Endocrinology 165 625-637.

Clarke IJ \& Cummins JT 1982 The temporal relationship between gonadotrophin releasing hormone $(\mathrm{GnRH})$ and luteinizing hormone (LH) secretion in ovariectomized ewes. Endocrinology 111 1449-1455.

Cone RD 1999 The central melanocortin system and energy homeostasis. Trends in Endocrinology and Metabolism 10 211-216.

Delavaud C, Bocquier F, Chilliard Y, Keisler DH, Gertler A \& Kann G 2000 Plasma leptin determination in ruminants: effects of 
nutritional status and body fatness on plasma leptin concentration assessed by a specific RIA in sheep. Journal of Endocrinology 165 519-526.

Diggle PJ, Liarg K-Y \& Zeger SL 1994 Analysis of longitudinal data. In Oxford Science Publications Series, vol 13, section 1.5, pp 18-21 Eds AC Atkinson, JB Copas, DA Pierce, MJ Scervish \& DM Titterington. Oxford: Clarendon Press.

Elias CF, Lee C, Kelly J, Aschkenasi C, Ahima RS, Couceyro PR, Kuhar MJ, Saper CB \& Elmquist JG 1998 Leptin activates hypothalamic CART neurones projecting to the spinal cord. Neuron 21 1375-1385.

Foster LA, Ames NK \& Emery RS 1991 Food intake and serum insulin responses to intraventricular infusions of insulin and IGF-1. Physiology and Behavior 50 745-749.

Gonzalez MI, Baker BI \& Wilson CA 1997 Stimulatory effect of melanin-concentrating hormone on luteinising hormone release. Neuroendocrinology 66 254-262.

Henry BA, Goding JW, Alexander WS, Tilbrook AJ, Canny BJ, Dunshea F, Rao A, Mansell A \& Clarke IJ 1999 Central administration of leptin to ovariectomized ewes inhibits food intake without affecting the secretion of hormones from the pituitary gland: evidence for a dissociation of effects on appetite and neuroendocrine function. Endocrinology 140 1175-1182.

Henry BA, Tilbrook AJ, Dunshea FR, Rao A, Blache D, Martin GB \& Clarke IJ 2000 Long-term alterations in adiposity affect the expression of melanin concentrating hormone and enkephalin but not proopiomelanocortin in the hypothalamus of ovariectomized ewes. Endocrinology 141 1506-1514.

Henry BA, Goding JW, Tilbrook AJ, Dunshea FR \& Clarke IJ 2001a Intraventricular infusion of leptin elevates the secretion of luteinizing hormone without affecting food intake in long-term food restricted sheep, but increases growth hormone irrespective of bodyweight. Journal of Endocrinology 168 67-77.

Henry BA, Rao A, Ikenasio BA, Mountjoy KG, Tilbrook AJ \& Clarke IJ $2001 b$ Differential expression of cocaine- and amphetamine-regulated transcript and agouti related-protein in chronically food-restricted sheep. Brain Research 918 40-50.

Kalra SP \& Kalra PS 1996 Nutritional infertility: the role of the interconnected hypothalamic neuropeptide Y-galanin-opioid network. Frontiers in Neuroendocrinology 17 371-401.

Kristensen P, Judge ME, Thim L, Ribel U, Christjansen KN, Wulff BS, Clausen JT, Jensen PB, Madsen OD, Vrang N et al. 1998 Hypothalamic CART is a new anorectic peptide regulated by leptin. Nature 393 72-76.

Lebrethon MC, Vandersmissen E, Gerard A, Parent AS \& Bourguignon JP 2000 Cocaine and amphetamine-regulatedtranscript peptide mediation of leptin stimulatory effect on the rat gonadotropin-releasing hormone pulse generator in vitro. Journal of Neuroendocrinology 12 383-385.

Leranth C, MacLusky NJ, Shanabrough M \& Naftolin F 1988 Immunohistochemical evidence for synaptic connections between pro-opiomelanocortin-immunoreactive axons and LH-RH neurons in the preoptic area of the rat. Brain Research 449 167-176.

MacRae JC, Bruce LA, Hovell FDDeB, Hart IC, Inkster J, Walker A \& Atkinson T 1991 Influences of protein nutrition on the response of growing lambs to exogenous bovine growth hormone. Journal of Endocrinology 130 53-61.

Malven PV, Haglof SA \& Degroot H 1992 Effects of intracerebral administration of neuropeptide- $\mathrm{Y}$ on secretion of luteinizing hormone in ovariectomized sheep. Brain Research Bulletin 28 871-875.

Mann GE, Lamming GE \& Fray MD 1995 Plasma oestradiol and progesterone during early pregnancy in the cow and the effects of treatment with buserelin. Animal Reproduction Science 37 121-131.

Marie M, Findlay PA, Thomas L \& Adam CL 2001 Daily patterns of plasma leptin in sheep: effects of photoperiod and food intake. Journal of Endocrinology 170 277-286.
Martin GB \& Walkden-Brown SW 1995 Nutritional influences on reproduction in mature male sheep and goats. Journal of Reproduction and Fertility. Supplement 49 437-449.

Matsubara C, Nishikawa Y, Yoshida Y \& Takamura K 1983 A spectrophotometric method for the determination of free fatty acids in serum using acyl-coenzyme A synthetase and acyl-coenzyme A oxidase. Analytical Biochemistry 130 128-133.

McCann JP, Bergman EN \& Beermann DH 1992 Dynamic and static phases of severe dietary obesity in sheep: food intakes, endocrinology and carcass and organ chemical composition. Journal of Nutrition 122 496-505.

McNeilly AS, Jonassen JA \& Fraser HM 1986 Suppression of follicular development after chronic LHRH immunoneutralization in the ewe. Journal of Reproduction and Fertility 76 481-490.

McShane TM, May T, Miner JL \& Keisler DH 1992 Central actions of neuropeptide-Y may provide a neuromodulatory link between nutrition and reproduction. Biology of Reproduction 46 1151-1157.

McShane TM, Petersen SL, McCrone S \& Keisler DH 1993 Influence of food restriction on neuropeptide-Y, proopiomelanocortin, and luteinizing hormone-releasing hormone gene expression in sheep hypothalami. Biology of Reproduction 49 831-839.

Mercer JG \& Speakman JR 2001 Hypothalamic neuropeptide mechanisms for regulating energy balance: from rodent models to human obesity. Neuroscience and Biobehavioral Reviews 25 101-116.

Mercer JG, Lawrence CB, Beck B, Burlet A, Atkinson T \& Barrett P 1995 Hypothalamic NPY and prepro-NPY mRNA in Djungarian hamsters: effects of food deprivation and photoperiod. American Journal of Physiology 269 R1099-R1106.

Mercer JG, Moar KM, Findlay PA, Hoggard N \& Adam CL 1998 Association of leptin receptor (OB-Rb), NPY and GLP-1 gene expression in the ovine and murine brainstem. Regulatory Peptides 75-76 271-278.

Mercer JG, Moar KM, Ross AW, Hoggard N \& Morgan PJ 2000 Photoperiod regulates arcuate nucleus POMC, AgRp and leptin receptor mRNA in Siberian hamster hypothalamus. American Journal of Physiology 278 R271-R281.

Miller DW, Blache D \& Martin GB 1995 The role of intracerebral insulin in the effect of nutrition on gonadotrophin secretion in mature male sheep. Journal of Endocrinology 147 321-329.

Miller DW, Blache D, Boukhliq R, Curlewis JD \& Martin GB 1998 Central metabolic messengers and the effects of nutrition on gonadotrophin secretion in sheep. Journal of Reproduction and Fertility 112 347-356.

Miller DW, Findlay PA, Morrison MA, Raver N \& Adam CL 2002 Seasonal and dose-dependent effects of intracerebroventricular leptin on luteinising hormone secretion and appetite in sheep. Journal of Endocrinology 175 (In Press).

Morrison CD, Daniel JA, Holmberg BJ, Djiane J, Raver N, Gertler A \& Keisler DH 2001 Central infusion of leptin into well-fed and undernourished ewe lambs: effects on feed intake and serum concentrations of growth hormone and luteinizing hormone. Journal of Endocrinology 141 1464-1469.

Nagatani S, Zeng Y, Keisler DH, Foster DL \& Jaffe CA 2000 Leptin regulates pulsatile luteinizing hormone and growth hormone secretion in the sheep. Endocrinology 141 3965-3975.

Peterson JI \& Young DS 1968 Evaluation of the hexokinase/ glucose-6-phosphate dehydrogenase method of determination of glucose in urine. Analytical Biochemistry 23 301-316.

Rhind SM \& McNeilly AS 1986 Follicle populations, ovulation rates and plasma profiles of LH, FSH and prolactin in Scottish Blackface ewes in high and low levels of body condition. Animal Reproduction Science 10 105-115.

Rhind SM, Leslie ID, Gunn RG \& Doney JM 1985 Plasma FSH, LH and prolactin and progesterone profiles of Cheviot ewes with different levels of intake before and after mating, and associated effects on reproductive performance. Animal Reproduction Science 8 301-313. 
Rhind SM, Leslie ID, Gunn RG \& Doney JM 1986 Effects of high levels of body condition and food intake on plasma follicle stimulating hormone, luteinizing hormone, prolactin and progesterone profiles around mating in Greyface ewes. Animal Production 43 101-107.

Rhind SM, McMillen S, McKelvey WAC, Rodriguez-Herrejon FF \& McNeilly AS 1989 Effects of the body condition of ewes on the secretion of $\mathrm{LH}$ and FSH and the pituitary response to gonadotrophin-releasing hormone. Journal of Endocrinology 120 497-502.

Rhind SM, McMillen S \& McKelvey WAC 1991 Effects of levels of food intake and body condition on the sensitivity of the hypothalamus and pituitary to ovarian steroid feedback in ovariectomized ewes. Animal Production 52 115-125.

Robinson JJ 1983 Nutrition of the pregnant ewe. In Sheep Production, pp 111-113. Ed. W Haresign. London: Butterworths.

Russel AJF, Doney JM \& Gunn RG 1969 Subjective assessment of body fat in live sheep. Journal of Agricultural Science: Cambridge $\mathbf{7 2}$ 451-454.

Schwartz MW, Sipols AJ, Marks JL, Sanacora G, White JD, Scheurink A, Kahn SE, Baskin DG, Woods SC, Figlewiz, DP et al. 1992 Inhibition of hypothalamic neuropeptide $\mathrm{Y}$ gene expression by insulin. Endocrinology 130 3608-3616.

Schwartz MW, Woods SC, PorteD Jr, Seeley RJ \& Baskin DG 2000 Central nervous system control of food intake. Nature $\mathbf{4 0 4}$ 661-671.
Stanley SA, Small CJ, Kim MS, Heath MM, Seal LJ, Russell SH, Ghatei MA \& Bloom SR 1999 Agouti related peptide (AgRp) stimulates the hypothalamo pituitary gonadal axis in vivo and in vitro in male rats. Endocrinology 140 5459-5462.

Tillet Y, Caldani M \& Batailler M 1989 Anatomical relationships of monoaminergic and neuropeptide $\mathrm{Y}$-containing fibres with luteinizing hormone-releasing hormone systems in the preoptic area of the sheep brain: immunohistochemical studies. Journal of Chemical Neuroanatomy 2 319-326.

Tjondronegoro S, Martin GB, Sutherland SR \& Boukhliq R 1996 Interactions between nutrition, testosterone and inhibin in the control of gonadotrophin secretion in mature rams. Reproduction, Fertility, and Development 8 855-862.

Williams LM, Adam CL, Mercer JG, Moar KM, Slater D, Hunter L, Findlay PA \& Hoggard N 1999 Leptin receptor and neuropeptide Y gene expression in the sheep brain. Journal of Neuroendocrinology 11 165-169.

Wilson BD, Bagnol D, Kaelin CB, Ollmann MM, Gantz I, Watson SJ \& Barsh GS 1999 Physiological and anatomical circuitry between agouti-related protein and leptin signaling. Endocrinology 140 $2387-2397$.

Received 22 May 2002

Accepted 23 July 2002 